\title{
Alveolar ridge preservation after dental extraction and before implant placement: A literature review
}

\section{Preservação do rebordo alveolar após a extração dentária e antes da colocação de implante: revisão da literatura}

\begin{abstract}
Several techniques and materials have been suggested for alveolar ridge preservation (ARP) after dental extraction and before implant placement. This literature review aimed to discuss the histological and clinical aspects of alveolar healing and the ARP procedure after dental extraction and to verify whether it allows dental implant placement (with or without further augmentation). Despite the heterogeneity of the studies, some evidence suggests that ridge preservation procedures are efficient in limiting the postextraction dimensional loss of the ridge and are accompanied by a different degree of bone regeneration, with varied amounts of residual graft material particles.
\end{abstract}

Key words: Tooth extraction; alveolar ridge preservation; guided bone regeneration; dental implants

\section{Resumo}

Várias técnicas e materiais têm sido sugeridos para a preservação do rebordo alveolar (PRA) após a extração dentária e antes da colocação do implante. Esta revisão de literatura buscou discutir os aspectos histológicos e clínicos da cicatrização do alvéolo e do procedimento PRA após a extração dentária e verificar se ele permite a colocação de implante dentário (com ou sem enxerto adicional). Apesar da heterogeneidade dos estudos, há evidência que os procedimentos de preservação do rebordo são eficazes na limitação da perda dimensional do rebordo pós-extração e são acompanhados por um grau diferente de regeneração óssea, com variadas quantidades de partículas residuais dos "materiais de enxerto".

Palavras-chave: Extração dentária; preservação do rebordo alveolar; regeneração óssea guiada; implantes dentários

\author{
Luis André Mezzomo a \\ Rosemary Sadami Shinkai a \\ Nikos Mardas ${ }^{b}$ \\ Nikolaos Donos ${ }^{b}$ \\ - Graduate program in Dentistry, Pontifical Catholic \\ University of Rio Grande do Sul, Porto Alegre, RS, \\ Brazil \\ b Periodontology Unit, UCL - Eastman Dental \\ Institute, London, UK
}

\author{
Correspondence: \\ Luis André Mezzomo \\ Avenida Princesa Isabel, 729, cj. 301 - Santana \\ Porto Alegre, RS - Brazi \\ 90.620-001 \\ E-mail: Imezzomo@hotmail.com
}

(This is a commissioned article)

Conflict of Interest Statement: The authors state that there are no financial and personal conflicts of interest that could have inappropriately influenced their work.

Copyright: (C) 2011 Mezzomo et al.; licensee EDIPUCRS. This is an Open Access article distributed under the terms of the Creative Commons AttributionNoncommercial-No Derivative Works 3.0 Unported License. 


\section{Introduction}

Dental implants have been successfully used in the rehabilitation of partially and completely edentulous patients (1). However, the outcome of treatment with implants is no longer measured exclusively in terms of implant survival, but also by the long-term esthetic and functional success of the prosthesis $(2,3)$. The successful esthetic and functional restoration of an implant depends on its optimal placement, which is influenced by its height and buccolingual position as well as by the alveolar ridge dimensions (4).

The loss of alveolar bone volume can occur before dental extraction due to periodontal disease, periapical pathology and trauma to the teeth and bone $(5,6)$. Additionally, the traumatic removal of teeth can cause bone loss and must therefore be prevented $(5,7)$. Finally, the alveolar bone suffers atrophy after tooth extraction, which has been well documented $(5,8,9)$. Thus, an understanding of the healing process of postextraction sites, including contour alterations caused by bone resorption and remodelling, is essential for obtaining functional and esthetically satisfactory prosthetic reconstructions (5-7).

The resorption and remodeling of the alveolar ridge after tooth removal is a natural healing phenomenon, which is physiologically undesirable and possibly inevitable and can negatively impact implant placement (10-12). This is particularly important in the anterior region of the maxilla, where a prominent root position is generally accompanied by an extremely fine and fragile vestibular wall that can be damaged during tooth extraction $(6,12-14)$. Thus, to meet the contemporary requirements of threedimensional, prosthetically-guided implant placement, the remaining alveolar ridge must be restored in most of the cases.

This literature review aimed to discuss the histological and clinical aspects of alveolar healing and the ARP procedure after tooth extraction and verify whether they allow dental implant placement (with or without further augmentation).

\section{The importance of correct three-dimensional implant placement}

Implant placement must be based on a restorationoriented treatment plan to allow the optimal support and stability of surrounding hard and soft tissues (2). Incorrect three-dimensional positioning can result in an improper implant/ restoration alignment, which, in turn, may cause poor esthetic and biological results. A more buccally implant placement can cause a significant risk of recession of the marginal mucosa. On the other hand, a more palatal placement can result in an inferior emergence profile or even restoration overhang. An inappropriate mesial-distal position can affect the size and form of the papilla and cause an undesirable embrasure form or an inadequate emergence profile. Finally, apical-coronal malposition can cause biological complications if the implant is placed very deeply, or esthetic complications if the metal of the implant shoulder is visible (3).

In addition to correct positioning, the esthetic outcome of the inserted implant can also be influenced by the amount of available bone in the implant site and its relation to soft tissues. The contour of soft tissues depends on the underlying bone anatomy because soft tissue dimensions are, at some extent, constant (15).

\section{Histological aspects of unassisted alveolar healing}

The alveolar process is a tooth-dependant tissue, and its architecture is oriented by the eruption axis, shape and eventual inclination of the teeth $(6,18)$. The tooth, in turn, is anchored to the maxilla through fibrous bone in which the periodontal ligament fibers are inserted. This fibrous bone obviously loses its function and disappears after tooth removal, resulting in alveolar process atrophy $(6,17)$.

Histological investigations in animals (17-19) and humans (20-22) have described the post-extraction healing of the alveoli. Amler et al. (20) and Amler (21) studies provided a pioneering description of the unassisted histological healing of alveoli in healthy humans. When a tooth is removed, a clot forms and is gradually replaced by granulation tissue in the base and periphery of the alveolus. New bone formation is evident after the first week, with osteoid matrix present at the alveolus base as noncalcified bone spicules. This osteoid starts to mineralize from the alveolus base in a coronal direction and fills two-thirds of the alveoli in approximately 38 days. At this stage, the first sign of a progressive resorption of the alveolar crest can be observed. This process is followed by a continuous reepithelialization, which completely covers the socket 6 weeks after extraction. The additional bone fill occurs, reaching maximum radiographic density around the hundredth day.

These initial histological results were recently corroborated by other studies using an animal model. It was observed that the healing tissue cells of the dental alveoli 4 weeks after tooth extraction are osteoblastic by nature and are committed to the formation of bone tissue (23). Moreover, Cardaropoli et al. (19) and Penteado et al. (23) have shown that bone formation occurs in a centripetal way; that is, it initiates from the old bone at the lateral and apical walls of the socket, due to the greater proximity to vessels and cell sources in these areas, and proceeds towards the wound center. Consequently, the synthesis of extracellular matrix protein is more advanced in the apical region than in the coronal region (23). Additionally, Cardaropoli et al. (19), based on the examination of post-extraction mesiodistal alveolar sections in dogs, found that (i) bone tissue filled the postextraction alveolus after one month, (ii) a cortical ridge including bone and lamellar tissue formed after 3 months, and (iii) after 3 months, the bone tissue was gradually replaced with lamellar and medullary bone. In addition, during the healing process, a cortical bone bridge was formed that "closed" the alveolus. In this last study, 
however, the information provided was restricted to internal alveolar alterations.

Araújo \& Lindhe (17) claimed that marked dimensional alterations with notable osteoclastic activity occurred during the first eight weeks after tooth extraction, resulting in resorption of the crestal region of both the buccal and lingual bone walls. Moreover, the resorption of the buccal and lingual walls of the extraction site occurred in two overlapping phases. In the first phase, the woven bone was resorbed and replaced with bone tissue. Because the buccal bone wall crest is exclusively composed of woven bone, this remodelling resulted in substantial vertical reduction of the buccal crest. The second phase showed that the resorption occurs from the external area of both bone walls, resulting in a horizontal resorption that can induce additional vertical reduction of the buccal bone.

\section{Anatomical consequences of unassisted alveolus healing}

Although the socket is filled with newly formed bone, the resultant defect will be only partially restored even with an uneventful healing (6). The loss of thickness is greater than the loss of alveolar ridge height after dental extraction, and both have been described as being more pronounced in the buccal aspect than in the palatal aspect of the jaws $(4,6-8,11,17,24-29)$.

In both jaws, the widest sockets (molars) show a significantly greater amount of resorption $(8,30)$ and require more time than the narrowest ones (incisors and pre-molars) for the formation of the bone tissue bridge over the defect (5). The degree to which the crest reabsorbs after the extraction is determined by the bone level at the extraction site, in despite of the bone level of the adjacent teeth. The sockets of teeth with horizontal bone loss heal more quickly because the reduced alveolar ridge level means less bone fill is necessary. This resorption process results in a narrower and shorter ridge, and the effect of this resorption pattern is the shifting of the ridge to a more palatal/ lingual position $(6,8,17)$. The dislocated ridge makes it more difficult to place the implant in an optimal restoration position without a buccal dehiscence occurring in the implant (4).

\section{Chronology of the socket healing}

The contours of the alveolar processes continuously change after teeth extractions because bone resorption and subsequent structural rearrangement occur (7). This remodelling happens in two phases: the initial resorption is part of the healing process and occurs more quickly in the first 3 months $(5,7,12,20,29)$. During this period, new bone formation and almost the entire loss of alveolar crest height happens simultaneously with a reduction of approximately two-thirds of the ridge width $(5,6,17,25)$. The process continues over the three following months. Between six and twelve months, part of this newly formed bone undergoes remodelling, and approximately $50 \%$ of the reduction of the alveolar ridge width occurs (5). The second phase is continuous and slower, occurring throughout the individual's life $(6,7)$.

\section{Disadvantages of the alveolar ridge augmentation after bone resorption and before implant placement}

Van der Weijden et al. (6), in a systematic review of the literature, found that, during the post-extraction healing period, the weighted means of the changes showed that the clinical loss of thickness $(3.87 \mathrm{~mm})$ was greater than the loss in height when evaluated both clinically $(1.67-2.03 \mathrm{~mm})$ and radiographically $(1.53 \mathrm{~mm})$. Because an 8 -mm-thick ridge is preferable for implant placement (4), the resorption that happens after tooth extraction can lead to a ridge approximately $4.1 \mathrm{~mm}$ thick, which is not adequate and will show a dehiscence when a 4-mm diameter implant is placed (11). Thus, an augmentation of the existing alveolar bone is necessary for the placement of the implant in a favorable prosthetic position $(1,12,16)$.

Implants placed in a site where the bone has been regenerated are acceptable and successful, and their success rates are comparable to those of implants placed in native bone $(14,31,32)$. Buser et al. (33) have demonstrated in preclinical studies that implants placed in regenerated bone associated with membranes osseointegrated successfully, and bone maturation continued after implant placement. Implant placement in post-extraction sites can generally be controlled with bone-graft procedures with high predictability, since at least two intact bone walls remain. However, as the time between extraction and implant placement increases, the progressive resorption of the ridge can result in a loss of bone volume in a degree that makes the simultaneous bone augmentation less predictable (34).

\section{Advantages of preventing resorption versus delayed reconstruction of the ridge}

Because the ridge dimensions are so crucial, it is advantageous to preserve the dimension of the postextraction ridge instead of reconstructing it thereafter, thus maintaining its ideal vertical and horizontal dimensions and decreasing patient morbidity $(4,14)$. Therefore, methods that ensure the preservation, augmentation or reconstruction of the alveolar ridge height, thickness and quality, immediately after dental extraction, either with bone regeneration procedures or with the placement of endosseous implants, seem to be essential for the maintenance of its vertical and horizontal dimensions. In fact, this would reduce the need for a later grafting, simplifying and optimizing the success of the implant placement in terms of esthetics and function $(3,5,11,12,16,26,35)$.

There has been a great interest in studies regarding alveolar ridge preservation in the esthetic anterior region (29). 
Some methods have been suggested to facilitate bone formation in freshly extracted sockets, thus minimizing the loss of bone height and buccolingual width. These include guided bone regeneration, following the principles proposed by Nyman et al. (36), with or without grafting material (11, $14,16,26)$; grafting with bone substitutes $(4,12,13,32,35)$; osteogenic materials, such as autogenous bone marrow (29) and plasma rich in growth factors (PRGF) (37); and other biomaterials (38-40). The grafting materials used as bone fillers after tooth extraction are able of providing a mechanical support and prevent the collapse of both the buccal and lingual bone walls, thus delaying residual ridge resorption and remaining in the place until enough healing (new bone formation) occurs (39). In other words, the ideal bone substitute materials must be osteoinductive and osteoconductive, stimulating and serving as a scaffold for bone growth.

The findings of a recent randomized clinical study of alveolar ridge preservation in 27 patients (41) confirmed that synthetic bone substitute (Straumann BoneCeramic ${ }^{\mathbb{R}}$, Straumann AG, Basel, Switzerland) or a bovine xenograft (BioOss ${ }^{\circledR}$, Geistlich Biomaterials, Wollhusen, Switzerland),

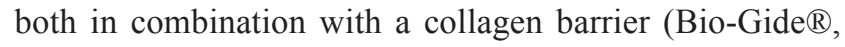
Geistlich Biomaterials, Wollhusen, Switzerland), equally preserved radiographic bone levels up to 8 months after post-extraction grafting of the sockets. Furthermore, the clinical study showed a reduction of less than $1.0 \mathrm{~mm}$ in the interproximal radiographic bone levels at 4 and 8 months post-surgery in both groups. It is questionable, however, whether radiographic alterations of less than 1.0 $\mathrm{mm}$ in the hard tissue of interproximal sites were clinically relevant.

Nevertheless, the use of grafting materials in fresh, post-extraction sockets has been questioned because they can interfere with the normal healing process $(14,32$, 38,39 ), and residual particles of the grafting material can be found surrounded by connective tissue or bone tissue in the socket up to 6 to 9 months after its insertion $(14,42)$. This interference is related to the way that these grafting materials are resorbed in the implant sites, which involves a giant cell response to a foreign body and activation in a later stage of the osteoclastic process (39). According to Norton \& Wilson (43), new bone formation inside the grafted socket cannot be histologically demonstrated in humans before at least 6 months of healing. The demonstration of reduced probing pocket depth and the radiographic image of the grafting materials have extrapolated the histological findings of animals and can lead to the conclusion, perhaps erroneous, that the grafting has been osteoincorporated (43).

The immediate placement of implants in fresh postextraction sockets has also been suggested, however with controversial results $(5,27,30,44-46)$. This technique can be negatively affected by the lack of soft tissue closure and the presence of infection and defects between the bone and implants (29). Recent clinical (27) and preclinical studies $(28,30)$ have demonstrated that implants placed in post-extraction sockets failed to prevent the remodelling that occurs in the socket walls, especially in the buccal aspect, which results in marginal loss of osseointegration.

Although the bone substitute material used is relevant, other aspects, such as socket morphology, the interproximal bone height and the presence and width of the buccal and lingual cortical walls influence the dimensional alterations of the bone after tooth extraction and the predictability of guided bone regeneration procedures. Although postextraction sockets with intact bone walls are capable of achieving bone regeneration by themselves $(12,26)$, the bone does not regenerate to a coronal level to that of the horizontal bone crest level of the neighboring teeth; i.e., a complete socket filling never occurs (5).

Fickl et al. (47) have demonstrated, in dogs, that flap elevation results in a more pronounced loss of ridge dimension than the non-elevation of a flap. This resorption and loss of alveolar bone height supposedly occurs due to the rupture of the periosteum and its connective tissue insertion into the bone surface. The consequent reduction of blood supply causes the lysis of the osteocytes and the necrosis of the mineralized tissue of the surrounding bony walls. This necrotic bone is thus gradually eliminated through the superficial resorption orchestrated by the osteoclasts in the periosteum $(12,17)$.

In addition, the elevation of a flap during bone grafting procedures may negatively affect the esthetics of the ridge and papilla $(4,35)$ by altering the mucogingival line position in the coronal direction (35). This is particularly relevant when using the socket preservation technique that includes occlusive barrier membranes. Three significant disadvantages are reportedly associated with this technique: (i) elevation of buccal and lingual flaps, in combination with tooth extraction, is necessary for membrane placement; (ii) the technique and the barriers need an advancement of the buccal flap for primary closure of the wound, in addition to a second surgery to remove the nonabsorbable membrane; and (iii) the exposure of nonabsorbable membranes to the oral environment during healing results in an increased risk of bacterial infection (9) and limited preservation of the alveolar bone, with results that are similar to those of unassisted socket healing (26). In light of this, Camargo et al. (35) discourage the use of regenerative procedures with flaps and membranes.

Whereas primary wound closure has been suggested as being able of improving wound stability (32) and offering better protection to the grafting materials (12), Penteado et al. (23), on the other hand, claimed that connective tissue ingrowth to the bone defect can disturb or completely prevent osteogenesis in thst area. In other words, the direct contact between the gingival connective tissue and the socket area, as seen when the flaps are advanced, would favour the resorption of the alveolar bone. When the gingival tissues are kept away from the socket area during the initial healing phases leaving and the socket opening is left exposed, less resorption of the alveolar bone occurs (35). 


\section{Absence of prospective clinical studies with the empty socket as control}

Although the interest in studies about socket preservation evaluating different techniques/ biomaterials has significantly increased within the last years, there are still few evidences based on controlled prospective clinical studies. The majority of the publications on humans are case report, case series or studies that do not include unassisted socket healing as control. Furthermore, many variables, including the defect type and size, the presence or absence of flap elevation, the presence or absence of primary wound closure, the type of graft used and the absence of reference points for reliable measurements make direct comparison between studies difficult (14).

In a recently published review, Darby et al. (3) showed that socket preservation techniques are effective in limiting horizontal and vertical ridge alterations in post-extraction sites and are followed by different degrees of bone formation and residual graft materials in the extraction socket. However, uncontrolled retrospective and prospective studies, as well as animal studies, were included in this review. Consequently, this may have led to incorrect conclusions due to the heterogeneity of the study designs, making the transposition of these results to the clinical reality.

In a recent systematic review of the literature (48), the results revealed that, despite the heterogeneity of techniques, materials and methodologies of the fourteen analyzed studies and the difficulty of making direct comparisons between them, evidence shows that physiological, threedimensional resorption of the alveolar ridge can be limited by several ridge preservation techniques. This reduction is significant in both the horizontal/ oral-facial dimension and the vertical/ apical-coronal dimension measured in the midbuccal aspect. However, none of the techniques or reported materials were capable of completely maintaining alveolar ridge dimensions. During the natural healing of the alveolus after dental extraction, a statistically significant reduction of the alveolar ridge in the horizontal/oral-vestibular dimension occurs. Controlled clinical studies showed average vertical bone resorption of 0.7 to $1.5 \mathrm{~mm}$, as well as an average horizontal resorption of 4.0 to $4.5 \mathrm{~mm}$ (12). Moreover, in the systematic review of Van der Weijden et al. (6), the weighed means of the changes showed a clinical loss of horizontal dimension to be greater than the vertical dimension loss. However, due to the heterogeneity of the data in the original articles, caution should be used when considering the metaanalysis performed in the above-mentioned review.

The height, width and number of bone walls of the resultant bone defect in the alveolus after the extraction, as well as the height of the alveolar bone in the interproximal aspects, are of great relevance $(3,26)$. The literature suggests that socket morphology has a critical impact on the outcomes of preservation efforts; that is, the more intact the bones walls are after the extraction, the more success can be anticipated for ARP procedures. Moreover, flap advance and closure by the primary method seem important to the ARP outcome (48).

\section{Final Considerations}

In summary, the literature suggests that the alveolar ridge preservation limits, but does not completely prevent the three-dimensional physiological resorption of the alveolar ridge after tooth extraction. This reduction is significant in the horizontal/buccal-palatal dimension, as well as in the vertical/apex-coronal dimension as measured in the midbuccal aspect. Clear evidences were not found to confirm the superiority of material over the other.

After tooth extraction, a significant reduction of the alveolar ridge in the horizontal/buccal-palatal dimension occurs if the socket does not receive some type of treatment. The bone filling of the socket can be significantly improved with preservation techniques. The maturation and mineralization of the newly formed bone in the extraction socket can be accelerated or improved by ridge preservation. This aspect can be clinically decisive during the preparation of a dental implant socket. A tissue with an immature aspect can be found even months after the tooth extraction and the filling of the socket with grafting material. This can lead to a primary stability of the implant, measured by the insertion torque, below the ideal parameters. allograft: a pilot study. J Periodontol 2002;73:94-102.

2. Buser D, Martin W, Belser UC. Optimizing esthetics for implant restorations in the anterior maxilla: anatomic and surgical considerations. Int J Oral Maxillofac Impl 2004;19(suppl): 43-61.

3. Darby I, Chen ST, Buser D. Ridge preservation techniques for implant therapy. Int J Oral Maxillofac Impl 2009;24(Suppl):260-71.

4. lasella JM, Greenwell H, Miller RL, Hill M, Drisko C, Bohra AA et al. Ridge preservation with freeze-dried bone allograft and a collagen membrane compared to extraction alone for implant site development: a clinical and histologic study in humans. J Periodontol 2003;74:990-9.

5. Schropp L, Wenzel A, Kostopoulos L, Karring T. Bone healing and soft tissue contour changes following single-tooth extraction: a clinical and radiographic 12-month prospective study. Int J Period Restor Dent 2003;23: 313-23. 
6. Van der Weijden F, Dell'Acqua F, Slot DE. Alveolar bone dimensional changes of postextraction sockets in humans: a systematic review. J Clin Periodontol 2009;36:1048-58.

7. Lam RV. Contour changes of the alveolar processes following extractions. J Prosth Dent 1960;10:25-32.

8. Pietrokovski J, Massler M. Alveolar ridge resorption after tooth extraction. J Prosth Dent 1967;17:21-7.

9. Simion M, Baldoni M, Rossi P, Zaffe D. A comparative study of the effectiveness of e-PTFE membranes with and without early exposure during the healing period. Int J Period Restor Dent 1994;14:166-80.

10. Tallgren A. The continuing reduction of the residual alveolar ridges in complete denture wearers: a mixed longitudinal study covering 25 years. J Prosthet Dent 1972;27: 120-32.

11. Lekovic V, Camargo PM, Klokkevold PR, Weinlaender M, Kenney EB, Dimitrijevic B et al. Preservation of alveolar bone in extraction sockets using bioabsorbable membranes. J Periodontol 1998;69:1044-9.

12. Aimetti M, Romano F, Griga FB, Godio L. Clinical and histologic healing of human extraction sockets filled with calcium sulfate. Int J Oral Maxillofac Impl 2009;24:902-9.

13. Guarnieri R, Pecora G, Fini M, Aldini NN, Giardino R, Orsini G. et al. Medical grade calcium sulfate hemihydrate in healing of human extraction sockets: clinical and histological observations at 3 months. J Periodontol 2004;75:902-8.

14. Nevins M, Camelo M, De Paoli S, Friedland B, Schenk RK, Parma-Benfenati S. et al. A study of the fate of the buccal wall of extraction sockets of teeth with prominent roots. Int J Period Restor Dent 2006;26:19-29.

15. Kan JY, Rungcharassaeng K, Umezu K, Kois JC. Dimensions of peri-implant mucosa: an evaluation of maxillary anterior single implants in humans. J Periodontol 2003;74:557-62.

16. Barone A, Aldini NN, Fini M, Giardino R, Calvo Guirado JL, Covani U. Xenograft versus extraction alone for ridge preservation after tooth removal: a clinical and histomorphometric study. J Periodontol 2008;79:1370-7.

17. Araújo MG, Lindhe J. Dimensional ridge alterations following tooth extraction. An experimental study in the dog. J Clin Periodontol 2005;32:212-8.

18. Claflin RS. Healing of disturbed and undisturbed extraction wounds. J Am Dent Assoc 1936;23:945-59.

19. Cardaropoli G, Araújo M, Lindhe J. Dynamics of bone tissue formation in tooth extraction sites. An experimental study in dogs. J Clin Periodontol 2003;30:809-18.

20. Amler MH, Johnson PL, Salman I. Histological and histochemical investigation of human alveolar socket healing in undisturbed extraction wounds. J Am Dent Assoc 1960;61:47-58.

21. Amler MH. The time sequence of tissue regeneration in human extraction wounds. Oral Surg Oral Med Oral Pathol 1969;27:309-18.

22. Boyne PJ. Osseous repair of the postextraction alveolus in man. Oral Surg Oral Med Oral Pathol 1966;21:805-13.

23. Penteado RP, Romito GA, Pustiglioni FEP, Marques MMM. Morphological and proliferative analysis of the healing tissue in human alveolar sockets covered or not by an e-PTFE Membrane: a preliminary immunohistochemical and ultrastructural study. Braz Oral Res 2005;4:664-9.

24. Johnson K. A study of the dimensional changes occurring in the maxilla after tooth extraction. Part I. Normal healing. Austr Dent J 1963;8:428-33.

25. Johnson K. A study of the dimensional changes occurring in the maxilla following tooth extraction. Austr Dent J 1969;14:241-4.

26. Lekovic V, Kenney EB, Weinlaender M, Han T, Klokkevold P, Nedic M. et al. A bone regenerative approach to alveolar ridge maintenance following tooth extraction. Report of 10 cases. J Periodontol 1997;68:563-70.

27. Botticelli D, Berglundh T, Lindhe J. Hard tissue alterations following immediate implant placement in extraction sites. J Clin Periodontol 2004;31:820-8.

28. Araúio MG, Sukekawa F, Wennström JL, Lindhe J. Ridge alterations following implant placement in fresh extraction sockets. An experimental study in the dog. J Clin Periodontol 2005;32:645-52.

29. Pelegrine AA, Costa CES, Correa MEP, Marques JFC Jr. Clinical and histomorphometric evaluation of extraction sockets treated with an autologous bone marrow graft. Clin Oral Impl Res 2010;21:535-42.

30. Araúio MG, Sukekava F, Wennström JL, Lindhe J. Tissue modeling following implant placement in fresh extraction sockets. Clin Oral Impl Res 2006;17:615-24.

31. Fugazzotto PA, Shanaman R, Manos T, Shectman R. Guided bone regeneration around titanium implants: report of the treatment of 1,503 sites with clinical reentries. Int J Periodontics Restorative Dent 1997; 17:292-9.

32. De Coster P, Browaeys H, De Bruyn H. Healing of extraction sockets filled with BoneCeramic $(\mathrm{R})$ prior to implant placement: preliminary histological findings. Clin Impl Dent Relat Res $2011 ; 13: 34-45$. 
33. Buser D, Ruskin J, Higginbottom F, Hardwick R, Dahlin C, Schenk RK. Osseointegration of titanium implants in bone regenerated in membrane protected defects: a histologic study in the canine mandible. Int J Oral Maxillofac Impl 1995;10:666-81 .

34. Zitzmann NU, Schärer P, Marinello CP, Schüpbach P, Berglundh T. Alveolar ridge augmentation with Bio-Oss: a histologic study in humans. Int J Period Restor Dent 2001;21:289-95.

35. Camargo PM, Lekovic V, Weinlaender M, Klokkevold PR, Kenney EB, Dimitrijevic B. et al. Influence of bioactive glass on changes in alveolar process dimensions after exodontia. Oral Surg Oral Med Oral Pathol Oral Radiol Endod 2000;90:581-6.

36. Nyman S, Lindhe J, Karring T, Rylander $\mathrm{H}$. New attachment following surgical treatment of human periodontal disease. J Clin Periodontol 1982;9:290-6.

37. Anitua E. Plasma rich in growth factors: preliminary results of use in the preparation of future sites for implants. Int J Oral Maxillofac Impl 1999; 14:529-35.

38. Serino G, Biancu S, lezzi G, Piattelli A. Ridge preservation following tooth extraction using a polylactide and polyglycolide sponge as space filler: a clinical and histological study in humans. Clin Oral Impl Res 2003;14:651-8.

39. Serino G, Rao W, lezzi G, Piattelli A. Polylactide and polyglycolide sponge used in human extraction sockets: bone formation following 3 months after its application. Clin Oral Impl Res 2008;19:26-31.

40. Fiorellini JP, Howell TH, Cochran D, Malmquist J, Lilly LC, Spagnoli D. et al. Randomized study evaluating recombinant human bone morphogenetic protein-2 for extraction socket augmentation. J Periodontol 2005;76:605-13.

41. Mardas N, D'Aiuto F, Mezzomo L, Arzoumanidi M, Donos N. Radiographic alveolar bone changes following ridge preservation with two different biomaterials. Clin Oral Impl Res $2011 ; 22: 416-23$

42. Becker W, Becker BE, McGuire MK. Localized ridge augmentation using absorbable pins and e-PTFE barrier membranes: a new surgical technique. Case reports. Int J Period Restor Dent 1994; 14:48-61.

43. Norton MR, Wilson J. Dental implants placed in extraction sites implanted with bioactive glass: human histology and clinical outcome. Int J Oral Maxillofac Impl 2002;17:249. 57.

44. Becker W, Becker BE, Hujoel P. Retrospective case series analysis of the factors determining immediate implant placement. Compend Contin Educ Dent 2000;21:805-8,8100$11,814-20$

45. Paolantonio M, Dolci M, Scarano A, d'Archivio D, di Placido G, Tumini V, Piattelli A. Immediate implantation in fresh extraction sockets. A controlled clinical and histological study in man. J Periodontol $2001 ; 72: 1560-71$.

46. Botticelli D, Renzi A, Lindhe J, Berglundh T. Implants in fresh extraction sockets: a prospective 5-year follow-up clinical study. Clin Oral Impl Res 2008;19:1226-32.

47. Fickl S, Zuhr O, Wachtel H, Bolz W, Huerzeler MB. Hard tissue alterations after socket preservation: an experimental study in the beagle dog. Clin Oral Impl Res $2008 ; 19: 1111-8$

48. Horváth A, Mardas N, Mezzomo LA, Needleman I, Donos N. Alveolar ridge preservation: A systematic review. Clin Oral Impl Res [In Press]. 